\title{
Uncovering a Painful Past: Archaeology and the Holocaust
}

Dr Caroline Sturdy Colls, Associate Professor of Forensic Archaeology and Genocide Investigation, Staffordshire University

\begin{abstract}
Places connected to the Holocaust, and the physical evidence that lies within them, survive as reminders of the crimes perpetrated by the Nazis. Both the treatment of these sites and attitudes towards them have varied considerably in the years since the Second World War. In recent years, a number of archaeological investigations have been instigated by curators at Holocaust sites in a direct attempt to enhance visitor experiences and education programmes. Archaeologists have initiated investigations at other forgotten and dilapidated sites in an attempt to raise awareness of these places. This paper will discuss two case study sites where archaeological investigations have been undertaken and where attempts have been made to inform conservation, heritage management and education strategies. It will highlight the various challenges that may arise in the course of developing dissemination tools and discuss strategies that have been adopted to account for them. Specifically it will focus on how archaeologists can present novel means by which to locate, record and re-present the physical evidence of the Holocaust and how they can tell the stories of difficult heritage sites even when traditional forms of memorialisation/muzealisation is not wanted or practical.
\end{abstract}

Keywords: Holocaust archaeology; commemoration; education; heritage management; difficult heritage; digital heritage

\section{Introduction}

Places connected to the Holocaust and the physical evidence that lies within them, survive as reminders of the crimes perpetrated by the Nazis. At some sites, an abundance of physical evidence remained visible on the surface after the Second World War and survives in the modern landscape (Hayes, 2003). However, at others, few traces appear to have survived. Some sites from this period have been incorporated into memorial and museum landscapes, whilst others have become dilapidated or overgrown (Sturdy Colls, 2015; Young, 1994). Others have been redeveloped with varying degrees of acknowledgement with regards to their former function. There is an equally diverse range of attitudes towards these sites. For many, they are seen as painful reminders of the past; some are places where people died and where people want to remember, but others may be places that people want to forget (van der Laarse, 2013). The diverse range of people connected to and affected by the Holocaust, both at the time and since, means that a wide range of ethical, religious, political and cultural issues exist in association with the spaces and places where crimes were perpetrated and where they are commemorated (Sturdy Colls, 2015 and 2012a). These issues present a number of challenges when attempting to preserve, present and commemorate sites. 
In recent years, an increase in archaeological investigations at Holocaust sites has led to a number of projects aimed at enhancing visitor experiences and education programmes. Most often, the artefacts uncovered during the course of excavations have been incorporated into new exhibitions or educational databases (Buchenwald and Mittelbau-Dora Memorials, 2014). On a larger scale, the discovery of structures, boundaries, mass graves and other features has led to the modification of memorials and landscapes (Pawlicka-Nowak, undated; Schute \& Wijnen, 2012; Kola, 2000). Most of these changes have been initiated by curators or the organisations responsible for protecting sites. However, archaeologists can have a key role to play in initiating dissemination and education programmes, and in developing novel forms of presentation that cater for a variety of different audiences.

This paper will discuss two case study sites where archaeological investigations have been undertaken and where attempts have been made to inform conservation, heritage management and education strategies. It will highlight the various challenges that may arise in the course of developing dissemination tools and discuss strategies that have been adopted to account for them. Specifically it will focus on how archaeologists can present novel means by which to locate, record and represent the physical evidence of the Holocaust and how they can tell the stories of difficult heritage sites when traditional forms of memorialisation/muzealisation is not wanted or practical.

\section{Treblinka Extermination and Labour Camps, Poland}

\section{Historical Background}

In 1941, a labour camp which came to be known as Treblinka I was constructed in a remote area of forest, north-east of Warsaw. Initially mainly Polish political prisoners were sent there and this was then followed by the deportation of Jews (Muzeum Walki i Męczenstwa w Treblince, 2011). Those interred in the camp had to undertake forced labour at the nearby quarry and railway line (Arad, 1987). It is estimated that between 10-12000 people died in the labour camp between 1941 and 1944 because of the brutal treatment they endured in the form of harsh living and working conditions, executions and torture (Arad, 1987). Some of the workers interred in the camp were also forced to construct the extermination camp that was built two kilometres to the north in 1942 (known as Treblinka II). In July that year, the extermination camp received its first transport. This camp was purposely designed to facilitate the execution of people in large numbers; aside from the barracks for those Jews tasked with removing the bodies from the gas chambers and disposing of the corpses, there was no living accommodation at Treblinka (Sturdy Colls, 2015). The complex of gas chambers, mass graves, cremation pyres and buildings were concealed in order to deceive victims into thinking that they were in a transit camp, and the site became the execution site of Jews, Roma, Sinti and political prisoners from across Europe (IMTN, 1947(3): 567-568). When the camp closed in August 1943 , following a prisoner revolt, the Nazis demolished it in an attempt to hide the traces of their crimes (Glazar, 1999). 
The current landscape of Treblinka eludes little to its former function as the location where over 800,000 people were murdered. Visitors to the site are faced with limited information about the events that occurred, and about the extent and nature of the extermination and labour camps which operated there. The lack of aboveground remains at the extermination camp and the lack of knowledge concerning its layout means that a definitive map of the site has never even been produced. The landscape is dominated by a memorial consisting of 17,000 stones (commemorating the cities, towns and villages from which people were sent to Treblinka), and symbolic representations of the camp boundary and railway platform (Figure 1). It is often assumed (incorrectly) by visitors that these symbolic representations accurately reflect the layout of the camp and that the large memorial obelisk is located on the area of the gas chambers. At the labour camp, the dilapidated foundations of some of the camp structures do survive, whilst others have become buried by overburden and dense vegetation (Figure 2). Only a handful of information boards exist, the majority of which are known to incorrectly indicate the locations and functions of specific buildings (see below).

Figure 1. The area of Treblinka extermination camp in Poland (C Caroline Sturdy Colls)

Figure 2. The area of Treblinka labour camp in Poland (C Caroline Sturdy Colls)

\section{Visitor Demographic}

Because Treblinka affected, and continues to affect, so many different groups and individuals, many people the world-over have an interest in the site. Some 50,000 people visit each year and they come from a diverse range of countries, backgrounds, religions and communities (Muzeum Walki i Męczenstwa w Treblince, pers. comm.). The majority (over 40,000) visit as part of group tours, most of whom are school groups from Israel. Historically, these Israeli groups do not visit the museum building, which is where the majority of historical information about the site is presented. Instead they hold ceremonies in the grounds of the memorial at the extermination camp. Presently, therefore, these groups receive little information about the history of the site and its broader role in the Holocaust, and they are not familiar with the layout of the site (except through information provided by their guides). At sites like Treblinka, where it is believed that the symbolic memorial accurately reflects the layout of the camp, tour guides in general often point out features to visitors and discuss the nature of the crimes perpetrated at these places. Yet archaeological research has demonstrated that these are not in fact the locations of the features being discussed with visitors, thus many visitors are being presented with an inaccurate impression of the camp.

Visitors also rarely visit the labour camp, quarry or execution site at Treblinka I, but instead visit only the extermination camp. This may be partly due to the fact that the two areas are geographically removed, being two kilometres apart and separated by a cobbled road. Although some visitors do make the drive down to the labour camp, 
this is not an easy undertaking given that the nature of the memorial path makes for difficult driving conditions. Due to the limited amount of time many visitors spend at the site, few walk between the two areas. During archaeological fieldwork at the site, the author has often been asked whether it is "worth" visiting the labour camp. Different visitors will of course have different views concerning what makes a site "worth" visiting. The presence or absence of standing remains seems to be a key factor for some. Yet, Treblinka I has surviving above-ground remains but receives fewer visitors than Treblinka II which has none, so this cannot be the sole factor. The amount of information provided for visitors, the nature of the memorial and what else there is to see seem to be key factors. The presence of marked mass graves seemed to convince some visitors it was worthwhile making the trip and highlighted the disappointment of some visitors that they were unable to see marked graves at the extermination camp. Almost certainly, some visitors do not visit the labour camp on the basis that fewer people were killed there, suggesting a somewhat worrying belief that the importance of a site is measured by the number of people killed.

Research suggests that there are many people who would like to visit Treblinka but they are unable to for a variety of reasons. The site is very remote and, although it is around two hour's drive from Warsaw, it is not on a major route. Many people from abroad may be unable to visit, including those whose relatives died in the camp. For some Orthodox Jews, visiting Treblinka is also difficult. They believe in not disturbing the remains of the deceased and, on the basis that human remains are scattered across much of the former extermination camp area some feel that it is not appropriate for them to walk there (Anon, pers. comm.; for an overview of Jewish Halacha Law see Sturdy Colls, 2015: ch.3 and Levine, 1997). Currently, for those unable to visit Treblinka who want to find out more information about it, there is no central resource where they can find detailed information about the camp's history.

\section{Archaeology and Re-Presenting Treblinka}

Since 2009, archaeological research undertaken at Treblinka by the author has generated a significant body of material. The results of this work are outlined elsewhere in Sturdy Colls (2015, 2014a, 2014b, 2013a and 2012b), and so will only be summarized here. The evidence uncovered - which includes photographs, documents, testimonies, maps, plans, field survey and geophysical data, artefacts and cultural memory research - has the potential to contribute to the commemoration of the victims who died at Treblinka and to increase public knowledge about the camps. This research has allowed new maps of the camps to be created; the locations of specific buildings (included the gas chambers) to be identified; previously unmarked mass graves to be found and belongings of the victims to be unearthed. It has allowed the original camp boundaries to be detected at both the labour and extermination camp, and it has allowed the various layers of the camps' post-war history to be uncovered. In fact, this research has demonstrated that, contrary to popular belief, a wealth of physical evidence relating to both the extermination and labour camps does in fact survive. 
In order to ensure that the material generated during these archaeological surveys was disseminated to a wide variety of people and through a variety of mediums, an associated dissemination project was developed by the archaeological team working at Treblinka. The main aim of this dissemination programme was to contribute to commemoration, conservation and education and to allow new research about the site to be encountered locally and globally (Centre of Archaeology, 2014). In the past, it has been observed by the author that the results of archaeological surveys at Holocaust sites are rarely integrated into historical narratives; rather the archaeological results are presented as an "add on" to the "known" history of a place, or they are overlooked or ignored (Sturdy Colls, 2015: ch.12). It is the intention of the dissemination programme at Treblinka to ensure that this does not occur there. Instead, it was decided that the findings should be presented in such a way that they supplement and complement historical sources, and enhance and inform commemoration and educational resources. Further project objectives included: the marking of the locations of recently identified structures and mass graves within both the extermination and labour camp sites; enhancing the information provided to visitors to the Museum of Struggle and Martyrdom in Treblinka, both within the museum and at the memorial sites in the areas of the former camps; and the creation of digital and online archives containing the material generated during the archaeological research, which can be accessed both at the site and remotely.

In the course of designing the dissemination programme for Treblinka, a number of important questions had to be considered. How could the dissemination programme enhance the information provided to visitors and account for the fact that they come from a variety of different backgrounds and communities? How could the dissemination programme account for the fact that many visitors do not go to the on-site museum and for the fact that there exists an interested demographic who are unable to visit the site at all? The solution to these questions was found by developing a multifaceted dissemination programme. The decision was taken to create an exhibition in the museum at Treblinka which would outline the results of the archaeological work to date and which would include the objects recovered from the site alongside the various other types of data generated by the survey. This exhibition has been designed to complement the existing museum exhibition and to further enhance the narrative of the camps. Information about the methods used during the archaeological research is also provided and specific findings in relation to the boundaries, buildings and mass graves within the camps have been outlined. The exhibition will be translated into four languages (English, Polish, German and Hebrew) to ensure that it is accessible to more visitors and is accompanied by an exhibition catalogue. In order to compensate for the fact that some visitors do not visit the museum at Treblinka, information boards have been designed which will be erected at the memorial site. These boards indicate the locations of features identified during archaeological survey and provide information about the role of these places in the camp system. As with the museum exhibition, one of the main aims of this part of the project was to reconnect the spaces and features at Treblinka with individual and collective stories. The information boards have been designed to present the physical evidence of the camps alongside the experiences of those 
housed within them. This serves to personalize the material remains, whilst providing a tangible body of evidence concerning the crimes perpetrated.

A number of measures will ensure that the newly uncovered evidence at Treblinka can be accessed by those unable to visit the site. Travelling versions of the exhibitions are planned throughout Europe, alongside an accompanying programme of educational activities (see below). A digital exhibition and archive, which will be available online via the Google Cultural Institute, is also under development. This online platform (which will also be accessible in each of the exhibition locations) will provide a sustainable educational resource, which can be used by members of the public, teachers, students and researchers. Based around a 360-degree tour of Treblinka and a catalogue of the materials uncovered during archaeological research, this resource creates a virtual environment that incorporates the history of Treblinka as an extermination and labour camp landscape, alongside information concerning its post-war history, which includes of course the archaeological research undertaken there (Figure 3). This resource strives to reconnect testimonies, objects, places and experiences within a virtual landscape. This resource will play a particularly important role in presenting the history of Treblinka to younger generations. A number of educational tools are also in the process of being developed with experts in pedagogy and Holocaust education.

Figure 3. A scene from the digital heritage resource which outlines the history of Treblinka and the results of recent archaeological survey (C Caroline Sturdy Colls)

In terms of the contents of the exhibition and associated materials, this too presented a number of challenges. Firstly, how can the complexities of the mass killings at Treblinka be represented? The archaeological research at Treblinka has demonstrated that people were killed and their bodies disposed of in a variety of different ways, many of which have been overlooked due to the "popular" history of the site (which suggests that all of the victims were killed in the gas chambers and cremated). How could the experiences of all of the victim groups present at the site be represented in a balanced fashion without one diminishing the experiences of another? Secondly, and connected to this, how could the whole landscape of Treblinka be presented, thus ensuring that the labour camp did not continue to be eclipsed by the extermination camp? New historical and archaeological research at the labour camp in particular has demonstrated the brutal treatment that those interred at Treblinka I were forced to endure (Sturdy Colls, forthcoming). It has also revealed the connections between the labour and extermination camps in terms of the movement of people, sensory experiences of inmates and guards, and the provision of labour and materials (Sturdy Colls, 2015: ch.4). The labour and the extermination camps, although separated by two kilometres, were part of the landscape of Treblinka but this is not currently apparent to visitors. One of the key challenges of the exhibition project was to find new ways to demonstrate the connections within this landscape and with other places across Europe, and to encourage visitors to visit both the extermination and labour camps. At the time of writing, the exhibition has yet to open and so its success in doing so cannot be 
assessed. However, it is hoped that it will provide a more coherent narrative of the two camps and highlight the experiences of all of a variety of different victims.

With regards to the in situ boards erected within the memorial landscape, it was necessary to question whether all of the features identified during the archaeological works should be marked. This was particularly problematic at the extermination camp where fieldwork is ongoing, where some features have only been partially characterised using non-invasive methods and where some features have yet to be located. The decision was made to mark only those features that had been conclusively identified and to continue to add to the in situ information over time as new research is undertaken and further fieldwork is carried out. The evolving nature of the exhibition reflects the evolving nature of the investigation at Treblinka.

\section{Staro Sajmište, Serbia}

\section{Historical Background}

In Belgrade, Serbia is an area referred to as the Old Fairground (Staro Sajmište). Situated on the banks of the River Sava, this site currently contains houses, shops, garages and car sales outlets, Roma settlements and artists' studios (Figure 4). Whilst on first glance this site appears similar to many other suburban areas, its history demonstrates how the modern landscape is the result of a complex series of interactions and reuses. In fact, the appearance of the site is a reflection of the various peaks and troughs in interest in acknowledging the site's difficult past.

Some of the buildings which still exist on the site were constructed in 1937 for a development called the Old Fairground, a group of exhibition halls that were at the centre of Serbia's industrial growth (Cultural Heritage Preservation Institute of the City of Belgrade, 2012). In 1941, the Old Fairground was occupied by the Nazis for the interment and extermination of Roma, political prisoners, and Jews and become known as the Judenlager Semlin (Byford, 2013; Jovanović, 2012; Schäfer, 1952). After 1942, the site became a detention centre (Anhaltlager Semlin) for communists, partisans and Chetniks. Between 1941 and 1942, it is estimated that approximately 18,100 were murdered and buried in mass graves, although the number could be significantly higher. Apart from two memorials, there is little to allude to the history of this site and the knowledge concerning the tragic events on a regional and international level is somewhat limited. The area is not frequented by visitors and no information exists at the site concerning its former functions.

Studies that have sought to understand the layout of this site during different periods of history have been complicated by the fact that Staro Sajmište represents a "Living Death Camp". Coined by Grupa Spomnik as part of the Forensic Architecture project, this title reflects the fact that the landscape is, and has been since 1944, a dynamic one where the living and the memories of the dead coexist (Forensic Architecture, 2014). Since the war, the site has been inhabited by a range of people from various economic backgrounds and has remained a prime target for industry. It area of the camp has become peoples' homes and their places of work whilst at the same time 
has remained a black spot on the New Belgrade cityscape due to its dilapidated nature. Yet for others, the site represents the place where their family and friends were murdered, a place which should be commemorated and where we should be reminded of past atrocity. Although discussions to memorialize and build a museum have continually surfaced since the 1950s, this has not yet been realized to due to issues with property ownership; an inability to agree about what the site should commemorate; different opinions on what development should take place, and most significantly, the fact that any such plans would result in the need for the relocation of the current population. In 2013, a partial forced eviction did take place with ground subsidence being the reported reason. The fact that people in Staro Sajmište have been displaced, or face eviction in the near future, is cruelly ironic given the camp's former function and this raises important questions about the ethical issues associated with affecting the current population of an area in the name of uncovering and commemorating Holocaust history.

As a result from the above issues, Staro Sajmište exists in a state of limbo. The site neither adequately commemorates the victims of the former camps nor offers adequate living conditions for the current residents; it neither sufficiently acknowledges the past nor looks ahead to the future. The continual modification of the site since World War II, coupled with its wartime and pre-war history, means that a number of layers of physical evidence and memories coexist in this area.

Figure 4. The area of the former Judenlager and Anhaltlager Semlin in Staro Sajmište, Belgrade, Serbia (C Caroline Sturdy Colls)

\section{Archaeology and Re-Presenting Staro Sajmište}

Under the direction of the author, and as part of the Living Death Camp Project, an archaeological investigation of the site of Staro Sajmište was undertaken to characterize and record these different layers of history. As well as defining the extent and nature of Staro Sajmište as it existed during the Holocaust, the project aimed to document its pre- and post-war history up to present day. Specifically, the project intended to disseminate information about the history of the site, to provide a permanent record of its history and to highlight the stories of those with a connection to the place.

These project aims were achieved through desk-based analysis (documentary and cartographic research and examination of photographic resources relating to various phases of the history of Staro Sajmište) and non-invasive field investigation (topographical and geophysical survey, laser scanning and airborne imagery). Cultural memory research was also undertaken to collate oral and written testimonies, video footage, documentary evidence, in-field observations and landscape analysis. The fieldwork demonstrated that many original camp buildings and features survive to date. Some structures survived almost in their entirety and had merely undergone cosmetic modifications due to reuse. Others were demolished but traces of them (in the form of foundations or vegetation change) were located, recorded and characterised. In conjunction with the location of the camp boundaries, roads and 
other areas used by prisoners, this allowed detailed maps of the camp to be produced for the first time. Because the material remains relating to the different period of the site's history were examined, a detailed history of how the landscape had evolved over time could be provided and the ways in which the Nazis made extensive use of existing man-made and natural landscape features were explored.. The results of this survey are outlined in full elsewhere (Forensic Architecture, 2014; Sturdy Colls, 2013b) and have only been summarised here since as the focus of this paper is the dissemination of archaeological results.

The presentation of the physical evidence alongside the documentary, cartographic, and photographic data enables the results to be used for education, heritage management and commemoration. The large amounts of digital data collected during the survey at Staro Sajmište facilitated the production of a number of digital heritage tools and forms of dissemination that accounted for the fact that in situ commemoration is not possible. The synthesis of this data was used to create successive phase plans of the site at different periods of history. The threedimensional model of the site which was created using the laser scanning and Ground Penetrating Radar (GPR) survey data now provides a permanent record of the condition of the site at the time of the survey, it allows the different layers of the site's history to be visualised and interpreted, and it provides a virtual tour of the site with accompanying historical information for those unable to visit (Figure 5). This model and the other materials generated by the survey were also incorporated into an international exhibition in Berlin (Haus der Kulturen der Welt, 2014). This exhibition, designed by the Forensic Architecture group from Goldsmiths College and the Haus der Kulturen der Welt specifically focused on Forensis, that is the investigation of sites of conflict in the public, as opposed to legal, realm (Forensic Architecture, 2014). Thus, by presenting the work at Staro Sajmište alongside other conflict sites, this exhibition demonstrated the potential of non-legal entities, such as archaeologists, researchers and the public, to investigate and present evidence of atrocities using a variety of freely available and emerging detection tools. The results of the project were also disseminated via a public lecture that took place within one of the former camp buildings (Oktobarski Salon, 2013).

Figure 5. One of the images from the three-dimensional model of Staro Sajmište, Belgrade, Serbia (C ScanLAB Projects)

\section{Discussion}

The examples provided above demonstrate the potential for archaeologists to generate materials and tools for commemoration, heritage management and education when addressing sensitive periods such as the Holocaust. The remainder of this paper will focus on a discussion of other pertinent issues that have arisen in the course of work undertaken by the author: the ways in which archaeologists can connect people and places, the role of digital heritage in relation to archaeological investigations of sensitive sites, and the role of archaeologists in education. Although this discussion centres on the Holocaust, it will be relevant to archaeologists and heritage professionals dealing with other events from the recent past. 


\section{Connecting People and Places}

When devising dissemination tools that relate to sites of atrocity, it is important to find ways to reconnect people and places in order to ensure that landscapes and narratives do not become sterile. After all, the evidence uncovered during archaeological surveys is a means to find out more about peoples' lives and, in the context of the Holocaust, the physical evidence often provides glimpses into the lives of victims, perpetrators and bystanders of crimes (Sturdy Colls, 2015). As part of in situ dissemination, as with the exhibition at Treblinka, providing witness testimonies alongside information about specific buildings and places is one means to achieve this. Presenting individual or groups of objects alongside information about their owners, and discussing landscapes in terms of what their architecture and layout would have meant for people interred there offer just two other possibilities. In a digital arena, this is perhaps even easier to do (Sturdy Colls and Colls, 2014). The creation of digital heritage tools that include the integration of maps, plans, aerial photographs, field survey data and photographs alongside witness testimonies and other documentary evidence has proven effective as part of both the Treblinka and Staro Sajmište projects outlined above. As part of the author's research on the island of Alderney in the Channel Islands, a project is currently in development to present information about individuals housed on the island during the Second World War, discovered as a result of mapping the graffiti they left in prison cells and on fortifications (Sturdy Colls et al, forthcoming). This project has allowed new information about the Occupation of the island to be recorded and ultimately it will also provide a valuable archive and commemoration tool that will document the lives of the individuals identified for the first time. In order to achieve these connections between people and places, it is important to adopt an interdisciplinary approach that includes historical research, archaeological fieldwork and cultural memory research, alongside the use of a variety of tools derived from computing, the arts and media studies.

\section{Digital Heritage and Ethical Issues}

The variety of digital heritage tools now available to archaeologists offers the possibility to enhance in situ heritage management and commemoration at Holocaust sites (Ch'ng et al, 2014; Deegan and McCarty 2012; Ledig 2009). As demonstrated by the examples presented above, they also provide an alternative means of commemoration and education at sites where in situ memorials or museums are not possible or wanted, or where people are unable to visit sites for whatever reason. They offer the possibility to integrate various different data types (as discussed above), to present information in a variety of formats and languages (thus catering for different users) and to cater for the needs of younger generations who may find digital media more engaging. The benefits of digital heritage tools in the context of Holocaust sites are discussed further in Sturdy Colls and Colls (2014).

The presentation of the findings of archaeological surveys through digital media in general is a relatively recent phenomenon and, in the context of the Holocaust, it has been undertaken even less often. A few very successful projects have been 
undertaken with regards to the Holocaust more generally which have presented online and digital heritage, and education platforms (Anne Frank House, undated; Jacobs \& Jacobs, undated). Along with the projects outlined above, these have demonstrated the potential for digital tools to be produced in such a way that the sensitivities surrounding this period of history can be accounted for. Although some discussions concerning the ethical issues surrounding the use of digital tools in the context of conflict archaeology have recently emerged (Sturdy Colls 2015, ch.12), these have been few in number. Just like archaeological field methodologies, there is no standard approach to developing digital (or indeed non-digital) dissemination tools. Not all approaches will be welcomed at all sites and some may even be seen as disrespectful. When devising such projects it is important to consider a number of important questions: What is it acceptable to reconstruct in a virtual environment when addressing sensitive histories? How can virtual representations of camps and execution sites be created without appearing disrespectful? What information should be presented alongside archaeological information in a virtual environment? How can archaeological data be presented in such a way that it is understandable to non-specialists and so that it does not appear only as scientific, clinical data? In relation to digital tools that are also to be used at Holocaust sites: How will tools be used at memorial spaces and museums? Could these uses be classed as disrespectful or disruptive by certain groups or individuals? Are these tools complementary to existing memorials and information? Are they necessary? The answers to these questions should be evaluated on a case-by-case basis via consultation with the various target audiences and other stakeholders with a connection to the site in question. For example, in the author's work at Treblinka, workshops and open forums have provided valuable opportunities to reflect on the needs and concerns of a wide range of groups and individuals and solutions have been developed with these in mind. Here and at Staro Sajmište, recording the modern landscape using laser scanners and photogrammetry (as outlined above) provided data which acted a backdrop to other forms of data presentation. This offered one way of providing more authentic virtual tours of sites whilst avoiding artificial forms of animation that may have been considered inappropriate.

\section{Education}

Very little has been written about the use of archaeological materials in Holocaust education despite the fact that the materials generated by archaeologists have the potential to be used in teaching and learning. In 2006, Darmanin and Mootz produced a compelling paper that highlighted novel approaches to using objects found during excavations of Holocaust sites in the classroom. They stressed that it was the everydayness of these things makes those stories more interesting for students than a dry text' (Darmamin and Mootz 2006, 1). Individual objects and the stories of those that owned them provide more tangible connections to the past, and can be used as a starting point to discuss broader narratives of the Holocaust with students and the public (Salmons, undated). The abundance of objects excavated by archaeologists has increased the body of material available to educators. Although they are quite rare, items bearing the names of specific people in particular can be an incredibly powerful tool to individualise the Holocaust (Sturdy Colls, 2015: ch.10). This is particularly important as many students who are 
otherwise unable to grasp the scale of the atrocities committed may be able to relate more readily to these personal experiences. Other items may reveal an insight into daily life, religious beliefs or relationships. Discussions concerning where objects were found may allow students to consider individual and collective journeys. For example, the items found near the gas chambers at Treblinka attest to the smuggling of items that occurred as people tried to hold on to their personal belongings (Figure 6). A project focusing on 'Ordinary Things', developed by the Centre for Holocaust Education at the University of London, serves as a valuable example of possible classroom activities centred on individual objects (Salmons, undated).

Figure 6. Some of the objects found at Treblinka near the gas chambers (C) Caroline Sturdy Colls)

However, beyond objects, there exists a number of other ways that material generated by archaeologists can be used in education. Maps, plans, satellite and airborne imagery, field survey and geophysical data, excavation reports and images can all contain a record of buildings, objects, infrastructure, graffiti, boundaries, graves and other body deposition sites (Figure 7). All of this material can form the basis of discussions with students concerning the nature and extent of genocide at the specific site being examined and the Holocaust more broadly. For Holocaust Memorial Day 2014 in the UK, the author was asked to deliver a number of sessions about the Holocaust for students of varying age groups. The sessions began by asking students to discuss what they knew about the Holocaust; first and foremost, were they actually aware that that particular day was Holocaust Memorial Day. Students were then asked to select from a list the countries that they believed that the Holocaust happened in. Following this, they were presented with the findings of recent archaeological investigations on Alderney in the UK Channel Islands, including the variety of different data types and materials generated. In the first instance, many of the students were surprised to discover that the Nazis had in fact committed atrocities on British soil and many interesting discussions followed about the victims and perpetrators, and why nothing was done to stop these atrocities from being carried out. This then led on to a discussion about the modern relevance of the Holocaust, as demonstrated by recent acts of anti-Semitism in the UK where Naziand Holocaust-related symbols, gestures and expressions have been recalled. Sessions have also been delivered with and by teachers, in collaboration with the Centre for Holocaust Education at the University of London, which have discussed what the physical evidence of the Holocaust, as uncovered by archaeological surveys, can reveal about the history of this period (Centre for Holocaust Education, 2014). Through the use of simple images, students were encouraged to examine the ways in which the physical evidence challenged or supported the popular histories of the Holocaust. This work forms part of a larger project intended to integrate the findings of archaeological research into the National Curriculum for History in the United Kingdom.

A number of Research-Informed Teaching projects have also been undertaken by the author that have provided students with the opportunity to participate in archaeological fieldwork at Holocaust sites. This has provided a very effective means 
by which to teach students about the Holocaust, to locate evidence pertaining to it, and to encourage them to question popular narratives of this period. Through initiatives such as mapping modern uses of sites and the graffiti they contain, and by facilitating engagement with local communities, students were also provided with an opportunity to evaluate more recent perceptions of sites and the events to which they relate. Thus it allowed them to consider issues such as genocide and racial hatred in modern society, alongside approaches to heritage management and conservation.

The process of carrying out archaeological fieldwork will also generate responses that may be indicative of prejudices that exist in modern society. The objections towards or acceptances of fieldwork, the encounters had whilst in the field and the responses that emerge after results are published can all provide interesting material for discussion. For many archaeologists, the attention received from Holocaust deniers may be unexpected and altogether unpleasant. In some cases, correspondence or internet postings made by them will include racist remarks levied against the victims of the Holocaust, those that believe that it happened and the researchers themselves. However, rather than simply dismissing these comments as merely mindless abuse, archaeologists can use these reactions, and those generated in other quarters, as an educational tool in order to discuss and highlight how many of the prejudices that underpinned the Holocaust still exist in modern society. In many cases, these reactions can demonstrate why the Holocaust is still a relevant issue today and why archaeologists should attempt to uncover evidence of the crimes perpetrated by the Nazis.

Finally, the educational value of Holocaust archaeology in terms of its ability to demonstrate how science, technology and the humanities can reveal new insights into historic events should not be overlooked. By discussing with, and involving students in, research, students may be inspired to engage more with their studies and to pursue further research themselves in the future. When attempting to disseminate work, there are clear benefits to archaeologists, historians and educators working together. A variety of classroom activities, lectures, workshops and visits can then be developed in order to ensure that students of all ages and the general public are able to learn more about archaeological research at Holocaust sites. It is hoped that, as more investigations at Holocaust sites take place, that the development of educational materials will become a standard part of archaeological methodologies.

Figure 7. A map regression of Staro Sajmište in Serbia showing the development of the camp which can be used in discussions concerning the development of genocide (C) Caroline Sturdy Colls and Google)

\section{Conclusion}

The landscape of the Holocaust is incredibly varied in terms of both the physical evidence that the crimes perpetrated by the Nazis left behind and the various ways it has been modified since. Attitudes towards the sites which it comprises are also 
equally diverse and have influenced the way that these events have been investigated, presented and acknowledged in the past. When undertaking archaeological fieldwork and research at Holocaust sites, archaeologists will (and should) be engaged in discussions concerning future possibilities for commemoration, heritage management and education. This paper has demonstrated just some of the tools and methods that are now at archaeologists' disposal which can be used to examine and disseminate information about this difficult heritage. By taking a proactive approach, various forms of dissemination are still possible even when in situ commemoration is not possible or wanted. Fortunately, archaeologists can draw upon a variety of methods, approaches and tools emerging in the digital humanities, computing and the arts in order to disseminate their findings (Sturdy Colls 2015: ch.12). Although not all methods will be appropriate for use in the context of Holocaust studies, providing the sensitivities and ethical issues involved in the examining of this period are considered, many novel options still remain available.

\section{References}

Anne Frank House. Undated. The Secret Annex Online. [online] [Accessed 14 April 2014]. Available at <http://www.annefrank.org/en/Subsites/Home/>

Arad, Y. 1987. Betżec, Sobibor and Treblinka: The Operation Reinhard Death Camps. Bloomington: Indiana University Press.

Buchenwald \& Mittelbau-Dora Memorials. 2014. [online] [Accessed 20 April 2014]. Available at $<$ http://www.buchenwald.de/fileadmin/buchenwald/fundstuecksammlung/index_ findbuch.html>

Byford, J. 2013 Semlin Judenlager in Serbian Public Memory. [online] [Accessed 12th August 2013]. Available at <http://www.semlin. info>

Centre of Archaeology 2014. Re-presenting Treblinka. [online] [Accessed 20 January 2014]. Available at: <http://blogs.staffs.ac.uk/archaeology/projects/holocaustlandscapes/genius-and-genocide/finding-treblinka/re-presenting/>.

Centre for Holocaust Education. 2014. Centre for Holocaust Education. [online] [Accessed 20 January 2014]. Available at: <http://www.holocausteducation.org.uk>.

Ch'ng, E., Gaffney, V., \& Chapman, H. 2014. Visual Heritage in the Digital Age. New York: Springer.

Cultural Heritage Preservation Institute of the City of Belgrade. "Information on the Cultural Monument - Old Fairground - A "Gestapo Concentration Camp" " in If Not Now, When...? Proceedings of the International Conference, The Future of the Site of the Old Fairground Staro Sajmište in Belgrade, 10th to 12th of May 2012. [online] 
[Accessed 12 April 2014]. Available at http://www.rs.boell.org/downloads/ Reader Sajmiste(3).pdf.

Deegan, M. \& McCarty, W. 2012. Collaborative Research in the Digital Humanities. Farnham: Ashgate Publishing.

Darmamin, M., and Mootz, D. 2006. Archaeology, the Classroom and the Holocaust: Telling Human Stories. Proceedings of the Yad Vashem International Conference [online] [Accessed 20 April 2014]. Available at:

<http://www1.yadvashem.org/education/conference2006/workshops.htm>.

Forensic Architecture. 2014. Forensis: The Architecture of Public Truth. Berlin: Sternberg Press.

Glazar, R. 1999. Trap with a Green Fence: Survival in Treblinka. Illinois. Northwestern University Press.

Haus der Kulturen der Welt. 2014. Forensis [online] [Accessed 30 June 2014].

Available at:

<www.hkw.de/en/programm/projekte/2014/forensis/start_forensis.php>.

Hayes, P. 2003. Auschwitz, Capital of the Holocaust: Review Essay, Holocaust and Genocide Studies, 17(2), 330-350.

IMTN (International Military Tribunal At Nuremberg). 1947. Trial of the Major War Criminals before the International Military Tribunal Nuremberg 14 November 1945 1st October 1946. Nuremberg. [online] [Accessed 20 October 2007]. Available at<http://www.loc. gov/rr/frd/Military_Law/NT_major-war-criminals.html>.

Jacobs, A. \& Jacobs, K. undated. Virtual Tour of Auschwitz-Birkenau. [online] [Accessed 09 June 2013]. Available at <http://www.remember.org/auschwitz>.

Jovanović, D. 2012 Roma in the Jewish Camp Zemun 1941-1942/ Romi u Jevrejskom Logoru Zemun 1941-1942" in If Not Now, When...? Proceedings of the International Conference, The Future of the Site of the Old Fairground Staro Sajmište in Belgrade, 10th to 12th of May 2012. [online] [Accessed 12th June 2013]. Available at <http://www.rs.boell.org/downloads/ Reader_Sajmiste (3).pdf, 23-39>. Cultural Heritage Preservation Institute of the City of Belgrade.

Kola, A. 2000. Betżec: The Nazi Camp For Jews in the Light of Archaeological Sources, Excavations 1997-1999. Poland: Council for the Protection of Memory of Combat and Martyrdom.

Ledig, C. 2009. The Faro Convention and the Information Society in Heritage and Beyond. In D. Thérond. (Ed.). Heritage and Beyond. Strasbourg-Cedex: Council of Europe, pp. 159-177. 
Levine, E. 1997. Jewish Views And Customs On Death. In C. Murray Parkes, P. Laungani, and B. Young, Death and Bereavement Across Cultures. London and New York: Routledge, pp. 98-130.

Oktobarski Salon. 2013. No one belongs here more than you. [online] [Accessed 1 August October 2013]. Available at <http://oktobarskisalon.org/2013/10/54oktobarski-salon-niko-ne-pripada-tu-vise-nego-ti?lang=en>.

Muzeum Walki I Męczeństwa w Treblince. 2011. [online] [Accessed 20 January 2011]. Available at:

$<$ http://www.treblinka.bho.pl/index.php?option=com_content\&task=view\&id= 6\&Itemid $=6>$.

Pawlicka-Nowak, L. Chełmno [online] [Accessed 30 June 2014]. Available at: <http://www.muzeum.com.pl/en/chelmno.htm>.

Salmons, P. undated. Ordinary Things? [online] [Accessed 20 April 2014]. Available at: <http://www.holocausteducation.org.uk/lessons/open-access/ordinary/>.

Schäfer, E. 1952. Ex-gestapo Chief for Serbia on Trial for Mass Murders. Quoted in JTA Article created 8th October 1952. [online] [Accessed 12th August 2013]. Available at <http://www.jta.org/1952/10/08/archive/ex-gestapo-chief-for-serbia-on-trial-formass-murders>.

Schute, I., \& Wijnen, J.A.T. 2012. De villa van Kamp Westerbork. Hooghalen, gemeente Midden-Drenthe. Een archeologisch en bouwbiografisch onderzoek. Volume 1. Weesp: RAAP Archaeologisch Adviesbureau BV.

Sturdy Colls, C. 2015. Holocaust Archaeologies: Approaches and Future Directions. New York: Springer.

Sturdy Colls, C. 2014a. Gone but not forgotten: Archaeological approaches to the landscape of the former extermination camp at Treblinka. Poland. Holocaust Studies and Materials 3. Warsaw.

Sturdy Colls, C. 2014b. Finding Treblinka: Archaeological Evaluation. Unpublished Fieldwork Report. Centre of Archaeology, Staffordshire University.

Sturdy Colls, C. 2014c Re-presenting Treblinka Project. [online] [Accessed 21 June 2014]. Available at: <http://blogs.staffs.ac.uk/archaeology/projects/holocaustlandscapes/genius-and-genocide/finding-treblinka/re-presenting/>.

Sturdy Colls, C. 2013a. Treblinka I: An Archaeological Assessment. Fieldwork Report, Centre of Archaeology, Staffordshire University. 
Sturdy Colls, C. 2013b. An Archaeological Assessment of the Area of the Former Judenlager and Anhaltlager at Staro Sajmište, Belgrade, Serbia. Fieldwork Report. Centre of Archaeology, Staffordshire University.

Sturdy Colls, C. 2012a. Holocaust Archaeology: Archaeological Approaches to Landscapes of Nazi Genocide and Persecution. Journal of Conflict Archaeology, 7(2), 71-105.

Sturdy Colls, C. 2012b. O tym, co minelo, lecz nie zostalo zapomniane. Badania archeologiczne na terenie bylego obozu zaglady w Treblince. Zaglada Zydow. Studia $i$ Materialy 8 (in Polish), 77-112.

Sturdy Colls, C., and Colls, K. 2014. Reconstructing a Painful Past: A Non-Invasive Approach to Reconstructing Lager Norderney in Alderney, the Channel Islands. In E. Ch'ng, V. Gaffney and H. Chapman. Visual Heritage in the Digital Age. New York: Springer, pp 119-146.

Van der Laarse, R. 2013. Beyond Auschwitz? Europe's Terrorscapes in the Age of Postmemory. Memory and Postwar Memorials: Confronting the Violence of the Past, 71.

Young, J.E. 1994. The Texture of Memory: Holocaust Memorials and Meaning. Prestel: Yale University Press. 